\title{
INFORMATION TECHNOLOGY APPLICATIONS IN CONSTRUCTION SAFETY ASSURANCE
}

\author{
Mirosław J. SKIBNIEWSKI \\ Department of Civil and Environmental Engineering, University of Maryland, College Park, MD 20742, USA \\ Institute for Theoretical and Applied Informatics, Polish Academy of Sciences, 44-100 Gliwice, Poland
}

Received 04 Sep 2014; accepted 10 Nov 2014

\begin{abstract}
Through analysis of articles published from 2006 to July 2014 this paper summarizes the topics of research and the institutions where research was conducted in the field of computer-based construction safety engineering management. One hundred and thirty-six articles published during this time focused on Information Technology (IT) applications in this field were selected for analysis. The underlying research topics and their related IT implementations are discussed, and research trends in allied specialties are identified.
\end{abstract}

Keywords: safety management, construction, building engineering, information technology, international research journal, research trends.

\section{Introduction}

Construction is one of the most dangerous industries, causing numerous casualties and property loss in every country around the world. Due to the improvement of production technology in construction, the ever expanding size and complexity of infrastructure projects, and increased expectations in regard to safety performance safety management has become a major challenge to the industry at large. Advances in safety sciences and information technology present an unprecedented opportunity to positively impact the safety performance in construction. There is a compelling need for further innovation to address challenges towards improving the safety performance of the construction industry globally (Kamardeen 2013).

Information technology-based field data acquisition equipment and tools are instrumental in achieving an ever increasing ability to store, retrieve, transmit and manipulate data and information during the conduct of construction projects. Precise and real-time control over workers, equipment, materials, construction methods and work environment are need for safety risk prevention and emergency response. Research on perceived risk based on sensors is conducted to monitor and analyze the safety status on construction sites to prevent workers from being exposed to hazards (Cheng, Teizer 2014; Nadar et al. 2013). Robotics and remotely controlled manipulators have been invented and are being improved for highsafety-risk construction activities (Jung et al. 2013; Han et al. 2006). Information systems have been widely discussed for managing massive multi-source heterogeneous data generated during construction and occupational hazard on site was assessed, so that consistent and timely data can be shared between project participants for effective safety collaborations (Lee et al. 2014; Dejjus, Antuchevičienè 2013).

Through the investigation of over one hundred and thirty articles from Web of Science ${ }^{\mathrm{TM}}$ and Scopus ${ }^{\mathrm{TM}}$ posted in the last 8 years, this paper presents a general review of research related to IT implementations in construction safety. All statistics in this paper are derived from these articles.

\section{Publication statistics}

From 2006 to July 2014, one hundred and thirty-six articles on Information Technologies for construction safety management were published or were available on the Web of Science $^{\mathrm{TM}}$ and in Scopus ${ }^{\mathrm{TM}}$. A subset of the compilation presented herein focused on papers from Automation in Construction, an international research journal (Skibniewski 2014). As shown in Figure 1, the increasing number of publications after 2008 indicates a growing concern for construction safety management and the growing number of proposed implementations of Information Technologies in this field. Research on construction site monitoring and worker/equipment safety has been carried out with the use of Radio Frequency Identification (RFID) technologies, Ultrawide Band (UwB) and Wireless Networks (WN), Building Information Modeling (BIM) applications, and others.

As shown in Table 1, the one hundred and thirty-six analyzed articles can be categorized into three major themes as follows: 1) Sensors and sensor-based systems for construction safety; 2) Robotics and manipulators for construction safety; 3) Information analysis and management along with reporting systems for construction safety. 


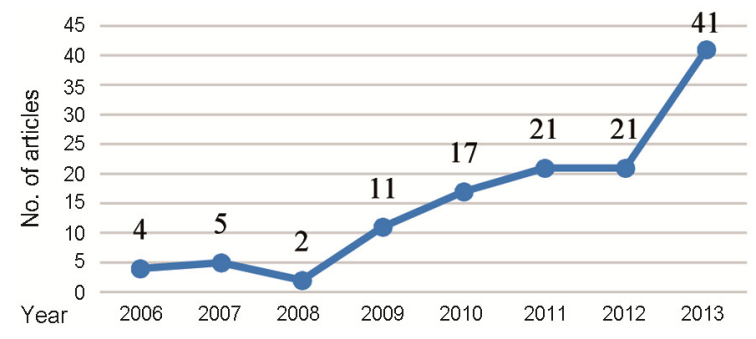

Fig. 1. Publications on IT in construction safety management

The top ten countries from which the largest number of published articles originated in the past 8 years are shown in Table 2. China, USA and Korea contributed $106(78 \%)$ of the articles. Considering the massive construction volume in China, a large volume of research on both worker and equipment safety has been reported

Table 1. Classification of articles on IT in construction safety published

\begin{tabular}{l|c|c}
\hline \multicolumn{1}{c|}{$\begin{array}{c}\text { Paper } \\
\text { Classification }\end{array}$} & $\begin{array}{c}\text { No. of } \\
\text { Articles }\end{array}$ & $\begin{array}{c}\text { Proportion to all Articles on } \\
\text { IT for Construction Safety } \\
\text { (January 2006 - July 2014) }\end{array}$ \\
\hline $\begin{array}{l}\text { Sensors and sensor- } \\
\text { based systems for } \\
\text { construction safety } \\
\begin{array}{l}\text { Robotics and ma- } \\
\text { nipulators for con- }\end{array}\end{array}$ & 37 & $27.21 \%$ \\
$\begin{array}{l}\text { struction safety } \\
\text { Information analysis } \\
\text { and management } \\
\text { and reporting sys- } \\
\text { tems for construc- } \\
\text { tion safety }\end{array}$ & 81 & $13.24 \%$ \\
Total & 136 & $59.56 \%$ \\
\hline
\end{tabular}

Table 2. Countries of origin of articles on IT in construction safety (per origin of the corresponding author)

\begin{tabular}{|c|c|c|c|}
\hline Country & $\begin{array}{c}\text { No. of } \\
\text { Articles }\end{array}$ & $\begin{array}{l}\text { Proportion to all } \\
\text { Articles on IT for } \\
\text { Construction Safety } \\
\text { (January 2006- } \\
\text { July 2014) }\end{array}$ & Rank \\
\hline $\begin{array}{l}\text { Greater China (incl. } \\
\text { PRC, Hong Kong, } \\
\text { Taiwan RoC) }\end{array}$ & 53 & $39 \%$ & 1 \\
\hline USA & 35 & $26 \%$ & 2 \\
\hline South Korea & 18 & $13 \%$ & 3 \\
\hline Canada & 5 & $4 \%$ & 4 \\
\hline Lithuania & 4 & $3 \%$ & 5 \\
\hline Italy & 3 & $2 \%$ & 6 \\
\hline Japan & 3 & $2 \%$ & 6 \\
\hline Australia & 2 & $1 \%$ & 8 \\
\hline England & 2 & $1 \%$ & 8 \\
\hline Finland & 2 & $1 \%$ & 8 \\
\hline Germany & 2 & $1 \%$ & 8 \\
\hline Poland & 2 & $1 \%$ & 8 \\
\hline Spain & 2 & $1 \%$ & 8 \\
\hline
\end{tabular}

involving the use of a variety of IT tools. Among other publications, researchers based in the USA and South Korea published five articles on their joint robotic and information systems research aimed at achieving improved construction safety performance.

Most active research institutions in IT for construction safety represented by corresponding authors are provided in Table 3 and statistics on corresponding authors in Table 4.

Table 3. Most active research institutions in IT for Construction Safety represented by corresponding authors

\begin{tabular}{c|c|l|c}
\hline Rank & Country & \multicolumn{1}{|c}{ Research institution } & $\begin{array}{c}\text { No. of } \\
\text { articles }\end{array}$ \\
\hline 1 & China & $\begin{array}{l}\text { (1) Huazhong University of Science } \\
\text { \& Technology } \\
\text { (2) Tsinghua University }\end{array}$ & 17 \\
& & (2) Southeast University & 3 \\
2 & \multirow{3}{*}{3} & (2) Wuhan University of Technology & 3 \\
& \multirow{3}{*}{ South } & (1) Georgia Institute of Technology & 14 \\
& Korea & (2) University of Michigan & 3 \\
& & (1) California State University & 2 \\
& & (1) Yonsei University & 3 \\
\hline
\end{tabular}

\section{Types of research on IT-based construction safety management}

\subsection{Sensors and sensor-based systems for safety}

Although construction professionals have made efforts to improve safety training, site supervision and design for safety, the safety performance in construction is still unsatisfactory, mainly due to human errors and lack of situational awareness during construction activities. Recent advances in sensing and computing technologies offer a solution for improving safety performance by providing rich information about location and worker safety (Marks, Teizer 2013).

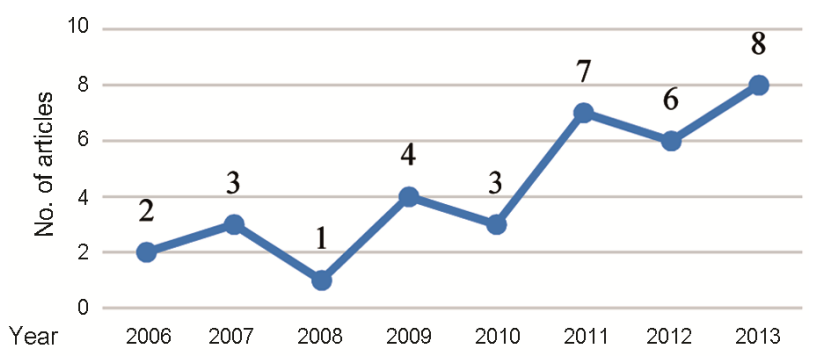

Fig. 2. Articles published between 2006 and 2013 on sensors and sensor-based systems for construction safety

There have been thirty-seven articles published on sensors and sensor-based system in the past 8 years, as shown in Table 5 and Figure 2. Twenty-four research institutions from seven countries and three continents have been active in research on this topic. Almost one third of these articles are focused on the use of RFID 
Table 4. Corresponding authors of papers on IT-based construction safety management

\begin{tabular}{|c|c|c|c|c|}
\hline Corresponding author & Research institution & $\begin{array}{c}\text { No. of articles by } \\
\text { Corresponding } \\
\text { Author }\end{array}$ & $\begin{array}{l}\text { Proportion to all articles on } \\
\text { IT for Construction Safety } \\
\text { (January } 2006 \text { - July 2014) }\end{array}$ & Rank \\
\hline Jochen Teizer & $\begin{array}{l}\text { RAPIDS Laboratory (formerly at Geor- } \\
\text { gia Institute of Technology) }\end{array}$ & 13 & $9 \%$ & 1 \\
\hline Lieyun Ding & $\begin{array}{l}\text { Huazhong University of Science and } \\
\text { Technology }\end{array}$ & 5 & $4 \%$ & 2 \\
\hline Alessandro Carbonari & Università Politecnica delle Marche & 3 & $2 \%$ & 3 \\
\hline Ruta Simanaviciene & Vilnius Gediminas Technical University & 3 & $2 \%$ & 3 \\
\hline Xianguo Wu & $\begin{array}{l}\text { Huazhong University of Science and } \\
\text { Technology }\end{array}$ & 3 & $2 \%$ & 3 \\
\hline Cheng Zhou & $\begin{array}{l}\text { Huazhong University of Science and } \\
\text { Technology }\end{array}$ & 2 & $1 \%$ & 6 \\
\hline Daehie Hong & Korea University & 2 & $1 \%$ & 6 \\
\hline Farnaz Sadeghpour & University of Calgary & 2 & $1 \%$ & 6 \\
\hline Ghang Lee & Yonsei University & 2 & $1 \%$ & 6 \\
\hline Jianping Zhang & Tsinghua University & 2 & $1 \%$ & 6 \\
\hline LeenSeok Kang & Gyeongsang National University & 2 & $1 \%$ & 6 \\
\hline M. Kasirossafar & California State University & 2 & $1 \%$ & 6 \\
\hline SangHyun Lee & University of Michigan & 2 & $1 \%$ & 6 \\
\hline Soungho Chae & Kajima Technical Research Institute & 2 & $1 \%$ & 6 \\
\hline Ying Ye & $\begin{array}{l}\text { Beijing Municipal Engineering Research } \\
\text { Institute }\end{array}$ & 2 & $1 \%$ & 6 \\
\hline Zhipeng Zhou & Southeast University & 2 & $1 \%$ & 6 \\
\hline
\end{tabular}

Table 5. Corresponding authors of papers on sensors and sensor-based systems for construction safety management

\begin{tabular}{|c|c|c|c|c|c|}
\hline Research institution & $\begin{array}{l}\text { Total no. of } \\
\text { articles from } \\
\text { institution }\end{array}$ & $\begin{array}{l}\text { Corresponding } \\
\text { author }\end{array}$ & $\begin{array}{c}\text { No. of articles by } \\
\text { Corresponding } \\
\text { Author }\end{array}$ & $\begin{array}{l}\text { Proportion to sensor and } \\
\text { sensor-based systems ar- } \\
\text { ticles on IT for Construction } \\
\text { Safety (January } 2006 \text { - July } \\
\text { 2014) }\end{array}$ & Rank \\
\hline Georgia Institute of Technology & 9 & $\begin{array}{l}\text { Jochen Teizer } \\
\text { Tao Cheng }\end{array}$ & $\begin{array}{l}8 \\
1\end{array}$ & $24 \%$ & 1 \\
\hline $\begin{array}{l}\text { Università Politecnica delle } \\
\text { Marche }\end{array}$ & 3 & $\begin{array}{l}\text { Alessandro } \\
\text { Carbonari }\end{array}$ & 3 & $8 \%$ & 2 \\
\hline $\begin{array}{l}\text { Kajima Technical Research } \\
\text { Institute }\end{array}$ & 2 & Soungho Chae & 2 & $5 \%$ & 3 \\
\hline University of Calgary & 2 & $\begin{array}{l}\text { Farnaz } \\
\text { Sadeghpour }\end{array}$ & 2 & $5 \%$ & 3 \\
\hline University of Southern California & 2 & $\begin{array}{l}\text { Burcin Becerik- } \\
\text { Gerber } \\
\text { Gulben Calis }\end{array}$ & $\begin{array}{l}1 \\
1\end{array}$ & $5 \%$ & 3 \\
\hline ACCIONA Infraestructuras & 1 & $\begin{array}{l}\text { Sara Prior } \\
\text { Peinado }\end{array}$ & 1 & $3 \%$ & 6 \\
\hline American University of Beirut & 1 & Hiam Khoury & 1 & $3 \%$ & 6 \\
\hline Chinese Academy of Sciences & 1 & Jianguo Yang & 1 & $3 \%$ & 6 \\
\hline $\begin{array}{l}\text { Chinese Academy of Surveying } \\
\text { and Mapping }\end{array}$ & 1 & Yan Lv & 1 & $3 \%$ & 6 \\
\hline Chung-Ang University & 1 & Hyeon-Jin Kim & 1 & $3 \%$ & 6 \\
\hline City University of Hong Kong & 1 & Ivan W.H. Fung & 1 & $3 \%$ & 6 \\
\hline Concordia University & 1 & $\begin{array}{l}\text { Saiedeh Nawab- } \\
\text { zadi Razavi }\end{array}$ & 1 & $3 \%$ & 6 \\
\hline $\begin{array}{l}\text { Environmental Management } \\
\text { College of China }\end{array}$ & 1 & Hong Fen Wang & 1 & $3 \%$ & 6 \\
\hline Kyonggi University & 1 & Gwanghee Kim & 1 & $3 \%$ & 6 \\
\hline
\end{tabular}


Continued Table 5

\begin{tabular}{|c|c|c|c|c|c|}
\hline Research institution & $\begin{array}{l}\text { Total no. of } \\
\text { articles from } \\
\text { institution }\end{array}$ & $\begin{array}{l}\text { Corresponding } \\
\text { author }\end{array}$ & $\begin{array}{l}\text { No. of articles by } \\
\text { Corresponding } \\
\text { Author }\end{array}$ & $\begin{array}{l}\text { Proportion to sensor and } \\
\text { sensor-based systems articles } \\
\text { on IT for Construction Safety } \\
\text { (January 2006 - July 2014) }\end{array}$ & Rank \\
\hline Lamar University & 1 & Seokyon Hwang & 1 & $3 \%$ & 6 \\
\hline Southeast University & 1 & Weiwei Wu & 1 & $3 \%$ & 6 \\
\hline Sungkyunkwan University & 1 & Su Won Yoon & 1 & $3 \%$ & 6 \\
\hline $\begin{array}{l}\text { The University of Texas at } \\
\text { Austin }\end{array}$ & 1 & Sooyoung Choe & 1 & $3 \%$ & 6 \\
\hline University of Arkansas & 1 & Haiyan Xie & 1 & $3 \%$ & 6 \\
\hline University of Michigan & 1 & SangHyun Lee & 1 & $3 \%$ & 6 \\
\hline University of Nebraska & 1 & Yong Cho & 1 & $3 \%$ & 6 \\
\hline University of Texas at Austin & 1 & Fernanda Leite & 1 & $3 \%$ & 6 \\
\hline $\begin{array}{l}\text { Xi'An University of Architec- } \\
\text { ture and Technology }\end{array}$ & 1 & Lichen $\mathrm{Gu}$ & 1 & $3 \%$ & 6 \\
\hline Yonsei University & 1 & Ghang Lee & 1 & $3 \%$ & 6 \\
\hline
\end{tabular}

(Calis et al. 2011; Chae 2009; Chae, Yoshida 2010; Kelm et al. 2013; Lee et al. 2012b; Li et al. 2012b; Marks, Teizer 2013; Peinado et al. 2009; Razavi et al. 2012; Xie et al. 2011; Yoon et al. 2006), a type of automatic identification technology in which radio wave frequencies are used to capture and transmit data from a tag, or transponder.

\subsubsection{RFID sensors}

The major applications of RFID sensors are the developments of safety early warning systems that could inform workers of potential safety risks on site. As shown in Figure 3, with real-time visible and traceable information, equipment collision accidents can be prevented if workers-on-foot and equipment operators have been warned or alerted when one gets too close to the equipment (Chae, Yoshida 2010). Besides conflict zone detection and vertical construction resource tracking, a threedimensional location-sensing algorithms have been developed to analyze the possible $3 \mathrm{D}$ locations of objects based on RFID sensor-generated information. However, the signal attenuation effect caused by the surrounding environment was not taken into consideration in these studies.

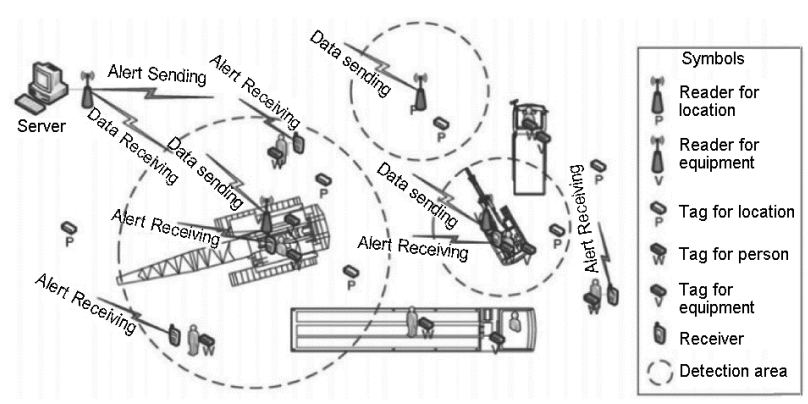

Fig. 3. Location of tags and divided excavation area (Chae, Yoshida 2010)
As ZigBee technology provides a reliable, low cost and easy to deploy wireless sensor network solution, researchers have explored the feasibility to use Zigbee RFID sensors networks to prevent workers from being struck by falling objects, and to track near-miss accidents by tracking the allocation of workers, equipment and materials (Wu et al. 2010). Although the field trial in a warehouse indicated the tracking signal would be weakened when emitters are obstructed, this problem can be overcome with a careful layout. Research on monitoring interference between teams at work can lead to the ability to alert project personnel of the occurrence of physical interference of work crews and to identifying and predicting problematic work conduct by workers (Naticchia et al. 2013). The RFID tags can be attached to safety gear such as Personal Protective Equipment (PPE) to support the compliance checking process (Kelm et al. 2013). In an event of non-compliance with safetymandated behavior, recording of the presence of workers on-site and checking whether any member of a team accessed an unauthorized area where interference with other work teams could take place would be possible. Nonetheless, a number of remaining problems need to be solved before such systems can be implemented in industry practice. Besides the concerns for capturing real-time information of workers on site, automatic, real time zoning updates of construction sites for safety, and registering potential risks using RFID tags are still among the unresolved issues. Technical and financial challenges with RFID-enabled safety precaution systems need to be further explored.

\subsubsection{Automated tracking based on ultra-wideband sensor}

Emerging wireless remote sensing technologies offer significant potential to advance the management of construction processes by providing real-time access to the locations of workers, materials, and equipment. Depending on site constraints and on the scope of management 
activities, past research has shown that predicting potential risk situations calls for real-time intelligent site monitoring and the ability to react when the level of risk increases. To date, the most promising tracking technology are RFID, Global Positioning System (GPS), Wireless Local Area Networks (WLAN), UwB and Indoor GPS, for their ability to cover a wide range of accuracy values and yard areas. UwB (Ultra-wide Band) is a radio-based technology that may be used at a very low energy level for short-range, high-bandwidth communications using a large portion of the radio spectrum. Unfortunately, little is known regarding the accuracy, reliability, and practical benefits of this emerging technology, effectively impeding widespread adoption. In face of that, efforts are made to evaluate the performance, including tracking accuracy, location error rates of a commercially available UWB systems for real-time, mobile resource location tracking in challenging construction environments (e.g. resource rich, spatially complex, cluttered with metallic objects causing interference). Sufficient accuracy for practical implementation was achieved in large open space construction environments (Cheng et al. 2011) (see Fig. 4).

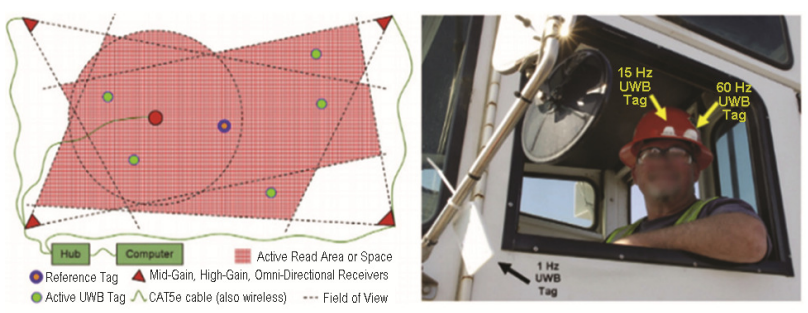

Fig. 4. Triangulation of UwB tags using UwB receivers that overlap the coverage area/space inside a lay-down yard (Cheng et al. 2011)

For outdoor automated applications of dynamic tracking based on an UwB technology, a prototype system for proactive safety management and real-time signalling of potential overhead hazards was developed. The system was conceived to act without the need to tag workers and other resources. Distances are in fact measured through IR and ultrasonic sensors. Its results suggest further system enhancement geared towards use cases involving dynamically changing hazardous areas (Carbonari et al. 2011). By consistently tracking the realtime position of workers involved on construction sites, measures can be taken to prevent non-authorized access to dangerous zones (Giretti et al. 2009). A method for preventing equipment collision by helping equipment operators improve their situational awareness while operating equipment on site was also reported. Although this study was only conducted at a laboratory scale, the reported research examined technical feasibility and expected benefits of integrating collision-prevention approaches with UWB technology for preventing equipment collisions (Hwang 2012).

For indoor scenarios, another study aimed at assessing performance of UwB tracking systems in a static mode under a set of conditions that can commonly occur on construction sites. The study measured the extent of the impact of variables that represent seven conditions that would have a negative impact on the accuracy of the location estimation data provided by UwB (Maalek, Sadeghpour 2013). The study reported an evaluation of the static and dynamic performance of a commercially-available UwB tracking system in free space and under realistic construction environment scenario. The results of these tests were in agreement with the manufacturer specifications for the UWB systems tested in outdoor environment (Saidi et al. 2011).

\subsubsection{Other sensor-based research}

For a construction equipment operator encountering blind spots, a navigation system that provides 3D information in real time about a building and its surroundings, and the position of the object being lifted have been developed using laser and encoder sensors (Lee et al. 2012a). Ultrasonic sensors are used to gradually obtain the accurate state of barriers, security judgment and Anti-Collision alarm through multi-sensor information fusion techniques (Li et al. 2012c). With positioning and personal ID sensors in the worker's hardhat, actual location of each worker is compared and verified with a database containing the tasks and processes being performed on site.

\subsection{Robotics and manipulators for safety}

The construction industry has been a challenging field for the application of robotic technologies. At the same time, the construction industry involves dangerous environmental characteristics which cause poor working conditions for construction laborers making it desirable to employ robots in the aid of, or instead of human workers (Skibniewski 1988). Replacing human labor with robotic systems has as the potential of increased quality, productivity and safety. Due to the complexity of research on robotics and manipulators, articles focused on this category of topics are relatively fewer than other categories analyzed in this paper, see Figure 5.

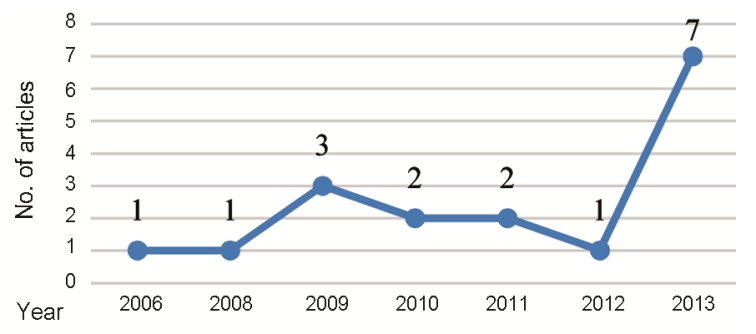

Fig. 5. Articles on robotics and manipulators for construction safety

\subsubsection{Human-machine interaction for automated construction}

Collaboration between a robot and a human worker during construction may be highly beneficial in achieving improved productivity and quality levels. In extreme project environments, construction robots may be the only equipment suitable for work performance, particularly in chemically or radioactively contaminated construction environments. For example, an automated 
excavation system, incorporating the intelligence of a construction planner and a skilful operator, has been developed to generate an optimal excavation plan based on 3D models of the structure being constructed in a given work environment and of the excavator (Seo et al. 2011). Other studies have focused on automated systems for lifting heavy structural components, transportation and assembly aiming at precise control of the work being performed. To cope with the lack of skilled workforce and with increased levels of hazards for human workers, a Genetic Algorithm-based Repetitive Tasks Simulation (CARTS) model has been developed for planning steel erection in high-rise building construction. The results have shown the model's capacity and justified its application to generic types of robotic construction systems (Yoo et al. 2012). A method based on strength tests for protective structures for construction equipment to prevent roll-over has been presented (Karliński et al. 2013).

A robotic beam assembly (RBA) system was developed to execute a beam assembly task (Jung et al. 2013), see Figure 6. Another application in steel construction focuses on a robotic performance of steel beam assembly. The robotic steel beam assembly system consists of a robotic bolting device that performs the main function for the beam assembly work and a robotic transport mechanism that transports the robotic bolting device to target bolting positions around a building under construction (Chu et al. 2013). Through field tests of the prototype and its application to a building construction project, the study shows the potential to replace laborers with a robotic system for steel beam assembly during high-rise building construction. Other research on vertical transportation in lifting construction materials to elevated locations where the material is to be installed, as an alternative to traditional tower cranes, has also been reported in the form of a robotic tower-crane system. Additionally, the feasibility of laser-technology-based lift-path tracking for a robotic tower-crane has been examined. Instead of traveling only through pre-planned paths, the proposed robotic tower-crane has shown the feasibility under various jobsite conditions (Lee et al. 2009). Research activities on tower crane visibility and operational conditions were conducted as well (Cheng, Teizer 2014; Tam, Fung 2011; Zhang et al. 2013c).

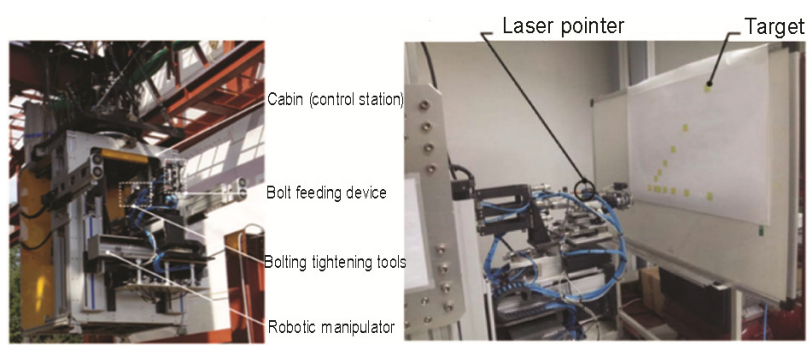

Fig. 6. The control devices in the cabin and experimental environment for the pointing task (Jung et al. 2013)

\subsubsection{Evaluation of current robotics and manipulators}

Pipe laying work involves the work of human laborers in trenches, one of the least safe construction tasks. Two papers published over the last decade discuss existing construction machinery for concrete pipe laying. One paper evaluates performance of the Hume Concrete Pipe Manipulator (HCPM) commissioned by the Korea Ministry of Construction and Transport. Based on the analysis of HCPM's overall work performance on a construction site, $65 \%$ in productivity improvement, and $33 \%$ in cost savings has been reported (Kim et al. 2009). Additionally, comparisons have been described between researches teams in Korea and in the US focused on installing large concrete pipe tele-robotically. Authors compare how the two research teams have solved some of the most unique technical problems in these operations, and present the lessons learned during the field tests without human personnel in the trench. Both prototypes reported improvements in productivity and unit cost (Kim, Elernold 2008).

Major institutions and corresponding authors on robotics and manipulators for construction safety management are provided in Table 6.

Based on the quantity of publications alone, it appears that Korea has had the most active research program in this field, as it has contributed $50 \%$ of all articles on robotics and manipulators for construction safety management. During the analyzed period a total of 16 research institutions from 8 countries and 4 continents have been active in this field.

\subsection{Information analysis, management and reporting systems for safety}

As shown in Figure 7, research papers related to BIM application to improving construction safety, laser scan status capture and early warning system were published in increasing numbers in 2013 due to the publication of a special issue based on expanded, updated and refereed papers presented at Australasian Conference on Innovative Technologies in Construction (ITC2012) in June 2012.

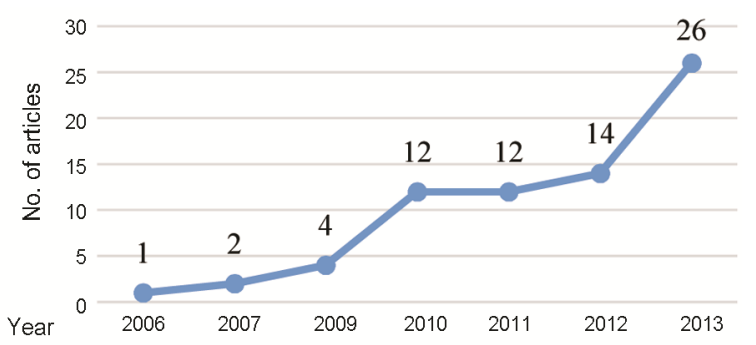

Fig. 7. Articles on information analysis and reporting systems for construction safety

As shown in Table 7, over 40 research institutions from 13 countries and 5 continents were involved in construction safety research focused on the implementation of IT tools. These institutions were based mostly in China and in the USA (Zhou et al. 2013b; Zhang et al. 2013b). 
Table 6. Major institutions and corresponding authors on robotics and manipulators for construction safety management

\begin{tabular}{|c|c|c|c|c|c|}
\hline Research institution & $\begin{array}{l}\text { Total no. } \\
\text { of articles } \\
\text { from } \\
\text { institution }\end{array}$ & $\begin{array}{l}\text { Corresponding } \\
\text { Author }\end{array}$ & $\begin{array}{c}\text { No. of articles by } \\
\text { Corresponding } \\
\text { Author }\end{array}$ & $\begin{array}{l}\text { Proportion to robotics and } \\
\text { manipulators articles on IT } \\
\text { for Construction Safety } \\
\text { (Jan. 2006 - July 2014) }\end{array}$ & Rank \\
\hline Korea University & 2 & $\begin{array}{l}\text { Daehie Hong } \\
\text { Hunhee Cho }\end{array}$ & $\begin{array}{l}1 \\
1\end{array}$ & $11 \%$ & 1 \\
\hline Yonsei University & 2 & $\begin{array}{l}\text { Ghang Lee } \\
\text { Hyoungkwan Kim }\end{array}$ & $\begin{array}{l}1 \\
1\end{array}$ & $11 \%$ & 1 \\
\hline $\begin{array}{l}\text { Changchun University of } \\
\text { Technology }\end{array}$ & 1 & Xinxing Tang & 1 & $6 \%$ & 3 \\
\hline Chongqing University & 1 & Nanqing Zhang & 1 & $6 \%$ & 3 \\
\hline Concordia University & 1 & Amin Hammad & 1 & $6 \%$ & 3 \\
\hline Georgia Institute of Technology & 1 & Jochen Teizer & 1 & $6 \%$ & 3 \\
\hline Hanyang University & 1 & Chang Soo Han & 1 & $6 \%$ & 3 \\
\hline Inha University & 1 & Young S. Kim & 1 & $6 \%$ & 3 \\
\hline Institute for Ferrous Metallurgy & 1 & Janusz Dobrzański & 1 & $6 \%$ & 3 \\
\hline $\begin{array}{l}\text { Kinki Regional Development } \\
\text { Bureau }\end{array}$ & 1 & Hiroshi Yamamoto & 1 & $6 \%$ & 3 \\
\hline $\begin{array}{l}\text { Korea Institute of Construction } \\
\text { Technology }\end{array}$ & 1 & Kyoon-Tai Kim & 1 & $6 \%$ & 3 \\
\hline Korea University & 1 & Daehie Hong & 1 & $6 \%$ & 3 \\
\hline $\begin{array}{l}\text { Seoul National University of } \\
\text { Science \& Technology }\end{array}$ & 1 & Sung-Keun Kim & 1 & $6 \%$ & 3 \\
\hline Universidad de Malaga & 1 & JC Rubio-Romero & 1 & $6 \%$ & 3 \\
\hline University of Western Sydney & 1 & Vivian W. Y. Tam & 1 & $6 \%$ & 3 \\
\hline $\begin{array}{l}\text { Wrocław University of } \\
\text { Technology }\end{array}$ & 1 & Mariusz Ptak & 1 & $6 \%$ & 3 \\
\hline
\end{tabular}

Table 7. Research institutions and corresponding authors on information analysis and reporting systems for construction safety management

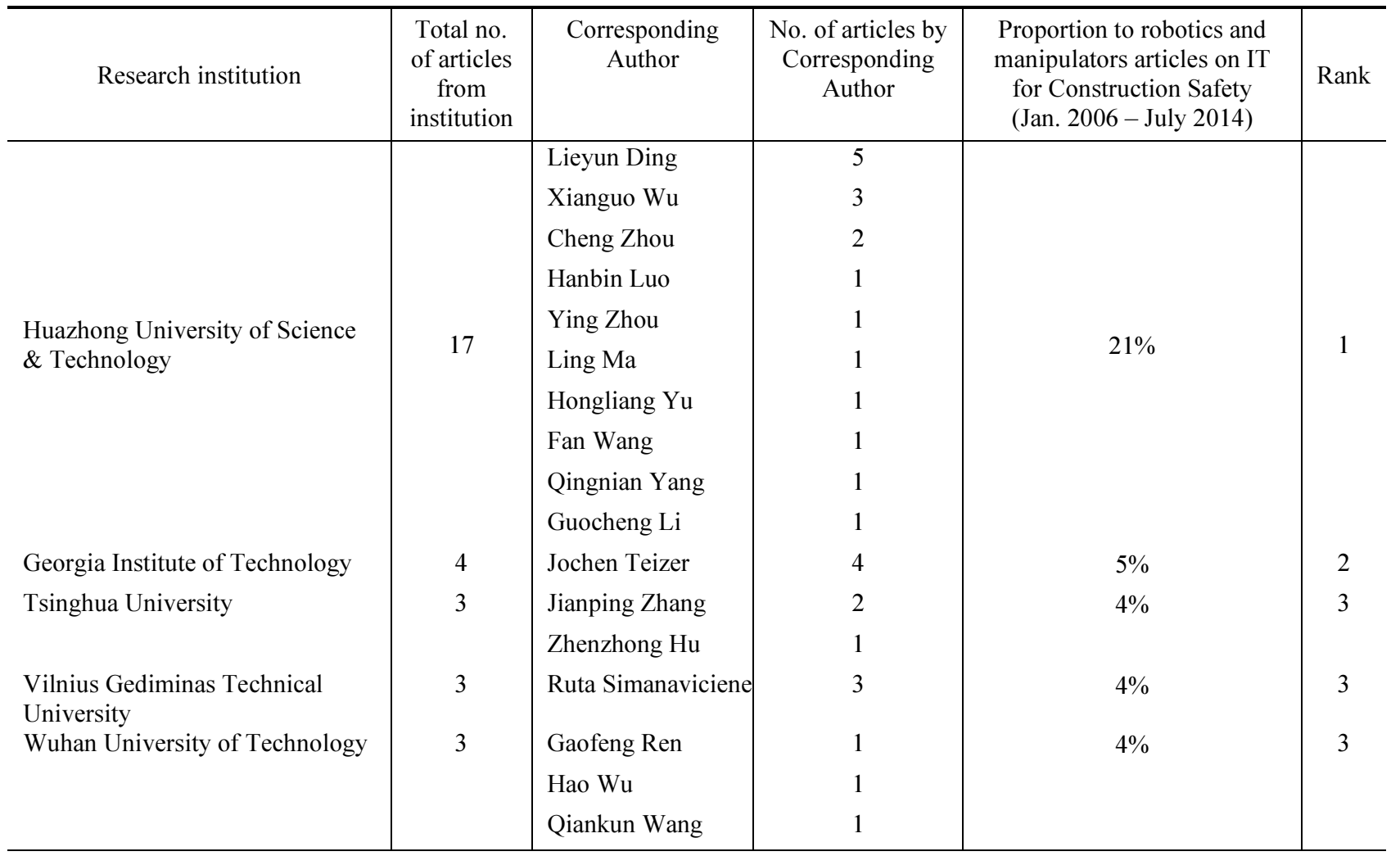


Continued Table 7

\begin{tabular}{|c|c|c|c|c|c|}
\hline Research institution & $\begin{array}{l}\text { Total no. } \\
\text { of articles } \\
\text { from } \\
\text { institution }\end{array}$ & $\begin{array}{l}\text { Corresponding } \\
\text { Author }\end{array}$ & $\begin{array}{l}\text { No. of articles by } \\
\text { Corresponding } \\
\text { Author }\end{array}$ & $\begin{array}{l}\text { Proportion to robotics and } \\
\text { manipulators articles on IT } \\
\text { for Construction Safety } \\
\text { (Jan. 2006 - July 2014) }\end{array}$ & Rank \\
\hline $\begin{array}{l}\text { Beijing Municipal Engineering } \\
\text { Research Institute }\end{array}$ & 2 & Ying Ye & 2 & $2 \%$ & 6 \\
\hline Beijing University of Technology & 2 & $\begin{array}{l}\text { Yanfeng Li } \\
\text { Wenxue Gao }\end{array}$ & $\begin{array}{l}1 \\
1\end{array}$ & $2 \%$ & 6 \\
\hline California State University & 2 & $\begin{array}{l}\text { Mohammad } \\
\text { Kasirossafar }\end{array}$ & 1 & $2 \%$ & 6 \\
\hline Chengdu University of Technology & 2 & $\begin{array}{l}\text { Yuping Qing } \\
\text { Lubo Meng }\end{array}$ & $\begin{array}{l}1 \\
1\end{array}$ & $2 \%$ & 6 \\
\hline Gyeongsang National University & 2 & LeenSeok Kang & 2 & $2 \%$ & 6 \\
\hline Southeast University & 2 & Zhipeng Zhou & 2 & $2 \%$ & 6 \\
\hline University of Colorado & 2 & $\begin{array}{l}\text { Matthew Hallowell } \\
\text { Behzad Esmaeili }\end{array}$ & $\begin{array}{l}1 \\
1\end{array}$ & $2 \%$ & 6 \\
\hline University of Michigan & 2 & $\begin{array}{l}\text { SangHyun Lee } \\
\text { Sanat A. Talmaki }\end{array}$ & $\begin{array}{l}1 \\
1\end{array}$ & $2 \%$ & 6 \\
\hline Virginia Polytechnic Institute & 2 & Dong Zhao & 1 & $2 \%$ & 6 \\
\hline VTT Technical Research Center & 2 & $\begin{array}{l}\text { Mani Golparvar- } \\
\text { Fard } \\
\text { Kristiina Sulankivi } \\
\text { Markku Kiviniemi }\end{array}$ & $\begin{array}{l}1 \\
1 \\
1\end{array}$ & $2 \%$ & 6 \\
\hline Anadolu University & 1 & Serkan Kivrak & 1 & $1 \%$ & 16 \\
\hline Arizona State University & 1 & $\begin{array}{l}\text { Samuel T. Ari- } \\
\text { aratnam }\end{array}$ & 1 & $1 \%$ & 16 \\
\hline Bauhaus-Universität Weimar & 1 & Juergen Melzner & 1 & $1 \%$ & 16 \\
\hline Beijing Polytechnic College & 1 & Shenglin $\mathrm{Wu}$ & 1 & $1 \%$ & 16 \\
\hline Buchting Streit AG & 1 & Karl Schikora & 1 & $1 \%$ & 16 \\
\hline
\end{tabular}

\subsubsection{BIM-based spatial-schedule conflict analysis and structural safety}

Schedule-workspace interference is generated when workspaces that share parallel schedules and are physically adjacent to one another exist simultaneously. When workspace interference is generated, securing work performance safety is difficult and constructability can deteriorate due to increased collision risk between resources. In view of this BIM was used for safety planning on site layout planning and visualization before construction (Kasirossafar, Shahbodaghlou 2013b; Kiviniemi et al. 2011; Sulankivi et al. 2009). For the construction phase of a project, a study related to situation awareness of equipment operators has been completed using Differential Global Positioning System (DGPS), wireless technologies. The researchers developed and implemented technologies for vehicle tracking and collision detection to sense their environment with the objective of increasing safety and improving productivity on construction sites. An active simulation system has been reported in 2014 using a genetic algorithm (GA) process for an alternative schedule that minimizes the level of interference in the schedule-workspace (Moon et al. 2014b). Based on new developments in BIM, four-dimensional (4D) technology, time-dependent structural analysis and collision detection, a 4D structural information model was presented as a proposed solution to spatial-scheduling conflicts and safety hazards during construction (Zhang, Hu 2011).

Using a combination of augmented reality (AR), location tracking, and game technologies, Korean researchers proposed a framework for BIM-based safety management and visualization, and a rule-based checking system to include automated hazard identification and abatement during the construction planning phase (Zhang et al. 2013d).

\subsubsection{Metro construction safety early warning systems}

As meaningful improvement in safety performance in metro construction is difficult, time-consuming and unreliable due to the lack of safety performance information and of experienced safety managers. Safety management in large-scale projects requires understanding and addressing technical and managerial complexities involved in the design and implementation of these projects (Zhou et al. 2010).

In pre-construction phrase, estimations of safety risk level and distribution for metro construction are made by very limited number of experts. Instant risk identification 
of risk management of metro and underground construction can be accomplished using an safety risk identification system (SRIS) based on construction drawings and risk identification rules to identify potential safety hazards, identify risks automatically and provide a basis for early warning and risk control (Ding et al. 2012).

In construction phrase, a web-based system was developed for safety risk early warning in urban metro construction and validated on several projects in China. A hybrid data fusion model based on multisource information (monitoring measurements, calculated predictions, and visual inspections) was employed to automatically imitate human experts giving safety risk assessment and early warning (Ding, Zhou 2013). To predict safety conditions on the construction site based on a multidimensional data model, a safety-oriented geotechnical instrumentation data warehouse was established integrating all data from heterogeneous sources for quick retrieval of information on site and for accident prevention (Ding et al. 2014).

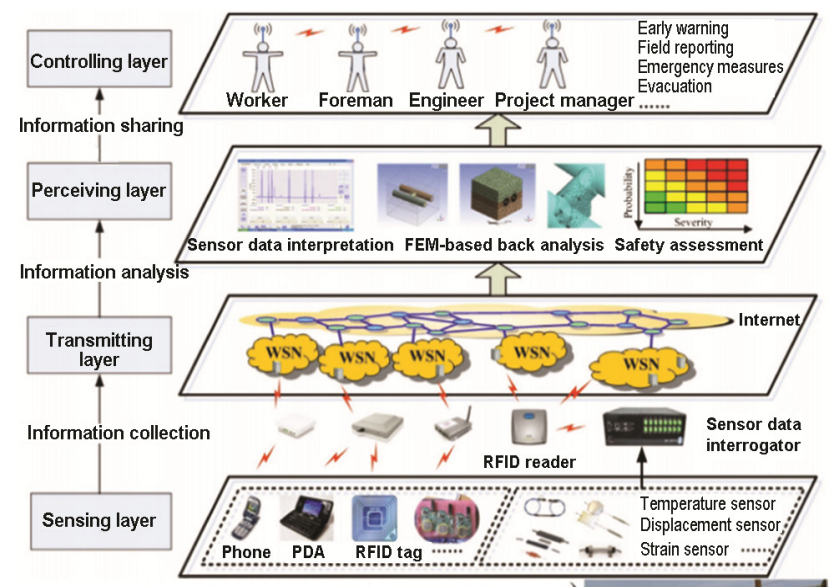

a)

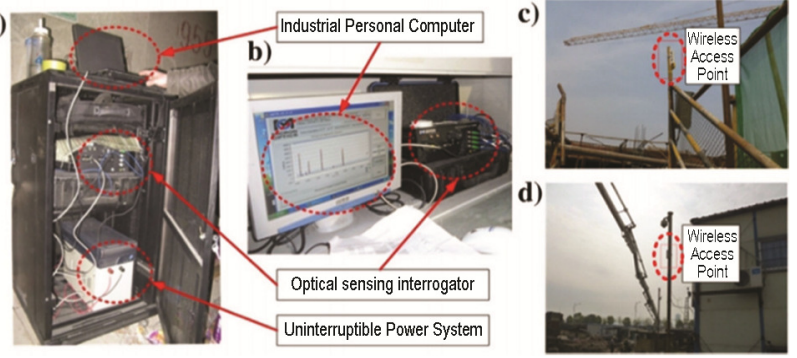

Fig. 8. Architecture of IoT-based safety early warning system and transmitting devices at the construction site (Ding et al. 2013b)

In order to improve web-based tools for construction safety management, "Internet of Things" (IoT) technology was introduced to create a sensor-saturated networked environment on a construction site, see Figure 8. With the seamless integration of a Fiber Bragg Grating (FBG) sensor systems and a RFID-based labor tracking systems, a comprehensive metro construction safety control system and devices were initially developed to overcome the risk control lags in the in construction process and verified through an application at the crossing passage in the Yangtze Riverbed Metro Tunnel project (Ding et al. 2013b). In addition, the research team deve- loped an original virtualized safety risk spatial-temporal coupling system to break through bottleneck of relying on single warning index for metro construction management based on BIM technology. So safety status of related components could be continuously visualized as conditions changed and potential safety risks evolved (Zhou et al. 2013a).

\subsubsection{Laser scan and range point cloud for spatial information acquisition}

For point cloud data acquisition and processing, accurate and rapid assessment of the as-built status on a construction site provides the opportunity to understand the current performance of a project. Rapid project assessment further identifies discrepancies between the as-built and as-planned progress, and facilitates decision making on the necessary remedial actions. To improve error-prone and time-consuming ways of conventional visual observations and surveying, research on automatic recognition of as-built condition and visualization of construction progress was conducted. For better accuracy and efficient data acquisition, performance evaluation of an Unmanned Aerial Vehicle (UAV) for mobile, rapid and autonomous acquisition of three-dimensional (3D) mapping data was carried out (Siebert, Teizer 2014), as shown in Figure 9. The combination of wireless communication with threedimensional laser scanning helps to realize image collection and display, image editing and analysis of the tunnel face, tunnel stability monitoring and personnel orientation management (Ye et al. 2009).

Efforts are made for robust automated recognition/ retrieval of 3D CAD objects in range point clouds in the Architectural/Engineering/Construction \& Facility Management (AEC-FM) context. However, more questions remain to be addressed and additional research is required for algorithms that automatically extract conventional or parametric CAD objects from laser scanners or imagebased point cloud models.

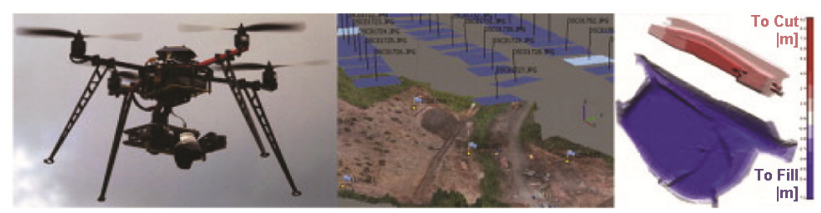

Fig. 9. An Unmanned Aerial Vehicle (UAV) for mobile and autonomous acquisition of for 3D mapping of built infrastructure (Siebert, Teizer 2014)

A 3D laser scanning of the earth's surface and a global positioning system (GPS) to obtain global geographic coordinates was presented for applications in construction projects through acquisition of landslide data and computing of earthwork volumes. Although thus calculated volumes may not be accurate when compared to conventional methods such as triangulation, field and office durations of operations could be reduced (Du, Teng 2007).

As the visibility of personnel and vital materials on construction sites are essential to equipment operators, the blind spots of construction equipment should be care- 
fully identified as part of the instruction routine in operator training. An automated blind spot detection tool was presented that determines the equipment blind spots rapidly and in 3D through analysis the point cloud data from a laser scan inside the equipment cab (Teizer et al. 2010), see Figure 10. Other application and practice of using point cloud data of equipment were presented and validated in a tunnel deformation monitoring ( $\mathrm{Wu}$ et al. 2013b).

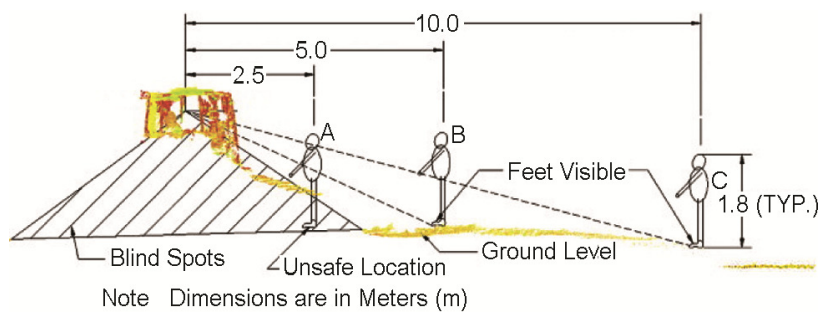

Fig. 10. Worker's visibility at different locations (A, B, and C) close to equipment (Teizer et al. 2010)

A synthesis method for multiple-attribute decisions has been proposed to increase the correctness of the rendered decisions by assessing alternative construction, technological and occupational safety solutions in uncertain jobsite conditions (Simanaviciene et al. 2012, 2014). Also, a multi-stage decision model reflecting a set of available combinations of alternatives has been developed to evaluate the effect of each criterion and its interaction with other criteria, which in turn assists with choosing appropriate solutions for structural design, construction technology and work safety challenges at hand (Liaudanskiene et al. 2012).

\section{Conclusions and future research}

\section{Conclusions}

Information technology has been applied in a wide array of applications to provide solutions to construction safety problems. Efforts made by researchers to assess the occupational safety (Dejjus, Antuchevičienè 2013), monitor performance of workers, equipment and construction environment, to replace human operations with robots and to collaborate among themselves are vital in creating a safe-working environment and in reducing casualties (Shin et al. 2014; Moon et al. 2014a; Ma et al. 2014; Kim et al. 2014; Han et al. 2014; Guo et al. 2014; Fung et al. 2014; Choe et al. 2014; Zhu et al. 2013; Zhang et al. 2013a; Ye et al. 2013; Wu et al. 2013a; Wang 2013; Sparer, Dennerlein 2013; Sepasgozar, Bernold 2013; Schikora et al. 2013; Rubio-Romero et al. 2013; Qin 2013; Melzner et al. 2013; Marzouk, Ali 2013; Marks et al. 2013; Luo et al. 2013; Li et al. 2013; Kivrak et al. 2013; Kim, Park 2013; Kasirossafar, Shahbodaghlou 2013a; Hinze et al. 2013; Hammad et al. 2013; Ding et al. 2013a, 2013c; Zhou et al. 2012; Zhao et al. 2012; Zhao, Ye 2012; Yang et al. 2012; Ren et al. 2012; Li, Hua 2012; Li et al. 2012a; Huang 2012; Hamidi et al. 2012; Gao et al. 2012; Esmaeili, Hallowell 2012; Yang, Ma 2011; Xue et al. 2011; Wang et al. 2011; Tang,
Yamada 2011; Shen, Zhu 2011; Maalek, Sadeghpour 2011; John, Ganah 2011; Guo et al. 2011; GolparvarFard et al. 2011; Ding et al. 2011a, 2011b; Chen et al. 2011; Aguilar, Hewage 2011; Yang et al. 2010; Yamamoto et al. 2010; Talmaki et al. 2010; Syachrani et al. 2010; Qi et al. 2010; Patel et al. 2010; Meng et al. 2010a, 2010b; Hu et al. 2010a, 2010b; Dobrzański, Pasternak 2009; Ding et al. 2010; Cheng et al. 2010; Zhang et al. 2009; Wang, Q. K., Wang, S. Q. 2009; Park et al. 2009; Lv, Zhu 2009; Teizer et al. 2008, 2007; Teizer, Castro-Lacouture 2007; Teizer 2007; Li et al. 2007; Nuntasunti, Bernold 2006; Cho, Youn 2006).

Research on sensors for fast and accurate tracking of construction resources for construction safety management was actively pursued in the past 14 years. Strategy for deployment of RFID sensor networks and their performance were among the most frequently discussed topics. A variety of technologies offered diverse capabilities for enhancing the overall safety performance. ZigBee, UWB, GPS, WLAN, and 3D virtualization technologies complement one another to increase reliability and timeliness of sensing and tracking locations in indoor or outdoor scenarios. Thus, it was worthwhile to examine the potential of hybrid systems comprising multiple technologies (Hwang 2012). Research in choosing and combining these technologies for most cost effective applications has been expected. For fast as-built status determination and compliance analysis, 3D laser scan technology was determined to be an efficient first step for spatial information acquisition. However, the accuracy and timeliness for automated recognition and retrieval of 3D BIM components from point clouds for dynamic construction process and object modeling remain to be studied further.

As demonstrated in Section 2, sensor-based systems, robotics and manipulators, and other IT-based systems are the three main research topics of the past decade in the realm of IT-based construction safety management. These technology-related aspects are closely connected to one another for achieving safe construction tasks, particularly with sensory data-saturated networks of on-site equipment.

The compilation conducted indicates that the leading research institutions contributing most of the last decade's research on IT-based construction safety performance solutions were Georgia Institute of Technology (Georgia Tech) and Huazhong University of Science \& Technology (HUST). Researchers led by Dr. Jochen Teizer, formerly at Georgia Tech in Atlanta, USA, and currently at STRABAG SE in Stuttgart, Germany, focused on real-time resource location tracking based on mobile laser scanning, automated three-dimensional as-built modeling, advanced safety for heavy equipment operation and work sites, virtual decision making environments, and safety performance learning tools. HUST Professor Lieyun Ding dedicated his team's activities to research on safety risk identification and risk containment in metro construction projects. Researchers on Professor Ding's team developed a metro construction safety control 
system and conducted research on lifecycle dynamic safety control for built infrastructure.

\section{Future research}

The use of BIM-based mobile applications will bring more interoperability and flexibility to field construction management. The combination of BIM and GIS technologies will create more location-based applications with the potential to integrate multiple BIM-based projects on a larger scale such as a city subdivision, municipal administrative units, and at even higher levels of jurisdiction. Also, precise indoor object recognition will help establish the corresponding relationship between as-build components and BIM elements for construction safety compliance verification.

A look at the on-going research awarded by USA and China's National Science Foundation (NSF) provides a perspective on government policies on science and technology in regard to IT-based construction management. More details are likely to become available upon the completion of the ongoing research in the USA and China as the corresponding authors from these two countries have historically contributed most of the articles on this particular topic.

In the last three years, there have been four new US National Science Foundation-supported research projects related to construction safety:

1. AIR Option 1: Technology Translation: Development and Evaluation of Field Prototype for Determining Excavator Proximity to Buried Utilities (University of Michigan, 2013);

2. GOALI: Geo-referenced Visualization and Emulated Proximity Monitoring for Real Time Knowledge-Based Excavator Control (University of Michigan Ann Arbor, 2012);

3. Collaborative Research: Correlating Geospatial Data Lineage and Positional Accuracy for Excavation Damage Prevention (Purdue University, 2013);

4. Collaborative Research: Automatic Behavior Monitoring for in-Depth Analysis of Construction Fatalities and Injuries (University of Michigan Ann Arbor, 2012).

In the last three years, China's National Science Foundation has funded the following seven construction safety projects:

1. Research on organization network model and case study of civil engineering construction safety knowledge sharing (HUST, 2014);

2. Behavior Simulation model and its application based on system dynamics modeling and multi-agent modeling related to civil engineering construction safety (Tsinghua University, 2014);

3. Study on the mechanism of unsafe behavior of construction workers and their application in construction safety management (Tsinghua University, 2013);

4. Construction safety control theory and method of metro adjacent bridge (Beijing Jiaotong University, 2014);
5. Study on the tunnel construction safety and control mechanism of blasting in confined space (Beijing Jiaotong University, 2013);

6. Metro safety monitoring data reconstruction and construction safety risk assessment based on Compressed sensing (HUST, 2013);

7. Study on impact of stakeholders behavior on construction safety mechanism and organizational behavior modification (China University of Mining \& Technology, 2011);

8. Research on real time early warning safety control of metro tunnel deformation based on uncertainty theory and Bayesian network (HUST, 2014).

Nearly half of the ongoing research focuses on underground construction safety management due to a massive volume of metro construction activities in China and their associated safety issues. Much of this effort has been reported in recent issues of various journals but not explicitly reviewed in this paper. The complexity and uncertainty of large-scale metro construction brings more technical and managerial challenges such as adjacent building foundation protection, severe geological conditions, tight construction schedules, newly applied innovative construction methods create new opportunities for current and future construction safety engineering and related IT research.

\section{Acknowledgments}

Valuable contributions and assistance of Miss Lijuan Chen, former visiting scholar with the University of Maryland's e-Construction Group, in data gathering and compilation that led to the publication of this article are gratefully acknowledged.

\section{References}

Aguilar, G. E.; Hewage, K. N. 2011. Real-time information and communication system to improve construction safety (C-RTICS 2), in Annual Conference of Canadian Society for Civil Engineering (CSCE 2011), 14-17 June 2011, Ottawa, ON, Canada, 2028-2039.

Calis, G.; Deora, S.; Li, N.; Becerik-Gerber, B.; Krishnamachari, B. 2011. Assessment of WSN and RFID technologies for real-time occupancy information, in Proceedings of the $28^{\text {th }}$ International Symposium on Automation and Robotics in Construction (ISARC 2011), 29 June - 02 July 2011, Seoul, South Korea, 182-188.

Carbonari, A.; Giretti, A.; Naticchia, B. 2011. A proactive system for real-time safety management in construction sites, Automation in Construction 20(6): 686-698. http://dx.doi.org/10.1016/j.autcon.2011.04.019

Chae, S. 2009. Development of warning system for preventing collision accident on construction site, in $200926^{\text {th }}$ International Symposium on Automation and Robotics in Construction (ISARC 2009), 24-27 June 2009, Austin, TX, United States, 55-60.

Chae, S.; Yoshida, T. 2010. Application of RFID technology to prevention of collision accident with heavy equipment, Automation in Construction 19(3): 368-374. http://dx.doi.org/10.1016/j.autcon.2009.12.008 
Chen, Y. C.; Chi, H. L.; Kangm, S. C.; Hsieh, S. H. 2011. A smart crane operations assistance system using augmented reality technology, in Proceedings of the $28^{\text {th }}$ International Symposium on Automation and Robotics in Construction (ISARC 2011), 29 June - 02 July 2011, Seoul, South Korea, 643-649.

Cheng, T.; Teizer, J. 2014. Modeling tower crane operator visibility to minimize the risk of limited situational awareness, Journal of Computing in Civil Engineering 28(3), 04014004.

http://dx.doi.org/10.1061/(ASCE)CP.1943-5487.0000282

Cheng, T.; Venugopal, M.; Teizer, J.; Vela, P. A. 2011. Performance evaluation of ultra wideband technology for construction resource location tracking in harsh environments, Automation in Construction 20(8): 1173-1184. http://dx.doi.org/10.1016/j.autcon.2011.05.001

Cheng, T.; Yang, J.; Teizer, J.; Vela, P. A. 2010. Automated construction resource location tracking to support the analysis of lean principles, in Challenging Lean Construction Thinking: What Do We Think and What Do We Know? $18^{\text {th }}$ Annual Conference of the International Group for Lean Construction (IGLC 18), 14-16 July 2010, Haifa, Israel, 643-653.

Cho, Y. K.; Youn, J. H. 2006. Wireless sensor-driven intelligent navigation robots for indoor construction site security and safety, in 2006 Proceedings of the $23^{\text {rd }}$ International Symposium on Robotics and Automation in Construction (ISARC 2006), 3-5 October 2006, Tokyo, Japan, 493498.

Choe, S.; Leite, F.; Seedah, D.; Caldas, C. 2014. Evaluation of sensing technology for the prevention of backover accidents in construction work zones, Journal of Information Technology in Construction 19: 1-19.

Chu, B.; Jung, K.; Lim, M. T.; Hong, D. 2013. Robot-based construction automation: An application to steel beam assembly (Part I), Automation in Construction 32: 46-61. http://dx.doi.org/10.1016/j.autcon.2012.12.016

Dejus, T.; Antuchevičienè, J. 2013. Assessment of health and safety solutions at a construction site, Journal of Civil Engineering and Management 19(5): 728-737. http://dx.doi.org/10.3846/13923730.2013.812578

Ding, L.; Li, W.; Zhou, G.; Wu, X. 2010. Environment settlements on embankment in wuhan yangtze river tunnel construction, in 2010 International Conference of Environment Materials and Environment Management (EMEM 2010), 2010, Harbin, China, 985-988. http://dx.doi.org/10.4028/www.scientific.net/AMR.113116.985

Ding, L.; Ma, L.; Luo, H.; Yu, M.; Wu, X. 2011a. Wavelet Analysis for tunneling-induced ground settlement based on a stochastic model, Tunnelling and Underground Space Technology 26(5): 619-628. http://dx.doi.org/10.1016/j.tust.2011.03.005

Ding, L.; Wang, F.; Luo, H.; Yu, M.; Wu, X. 2013a. Feedforward analysis for shield-ground system, Journal of Computing in Civil Engineering 27(3): 231-242. http://dx.doi.org/10.1061/(asce)cp.1943-5487.0000219

Ding, L.; Wu, X.; Luo, H.; Fu, F. 2011b. Research on standard for construction safety assessment of metro engineering, Tumu Gongcheng Xuebao/China Civil Engineering Journal 44(11): 121-127.

Ding, L.; Yu, H. L.; Li, H.; Zhou, C.; Wu, X.; Yu, M. H. 2012. Safety risk identification system for metro construction on the basis of construction drawings, Automation in Construction 27: 120-137. http://dx.doi.org/10.1016/j.autcon.2012.05.010
Ding, L.; Zhang, L.; Wu, X.; Skibniewski, M. J.; Qunzhou, Y. 2014. Safety management in tunnel construction: Case study of Wuhan metro construction in China, Safety Science 62: 8-15.

http://dx.doi.org/10.1016/j.ssci.2013.07.021

Ding, L.; Zhou, C. 2013. Development of web-based system for safety risk early warning in urban metro construction, Automation in Construction 34: 45-55. http://dx.doi.org/10.1016/j.autcon.2012.11.001

Ding, L.; Zhou, C.; Deng, Q. X.; Luo, H.; Ye, X. W.; Ni, Y. Q.; Guo, P. 2013b. Real-time safety early warning system for cross passage construction in Yangtze Riverbed Metro Tunnel based on the internet of things, Automation in Construction 36: 25-37. http://dx.doi.org/10.1016/j.autcon.2013.08.017

Ding, L.; Zhou, C.; Ye, X.; Luo, H.; Ni, Y.; Guo, P. $2013 \mathrm{c}$. Study on real-time sensing and early-warning of construction safety risk for metro crossing passage under Yangtze River, Tumu Gongcheng Xuebao/China Civil Engineering Journal 46(7): 141-150.

Dobrzański, J.; Pasternak, J. 2009. Reliability and safety of the power equipment in respect of properties evaluation of welded joints made from new generation creep-resisting steels, in Pressure Vessels and Piping Conference (ASME), 26-30 July 2009, Prague, Czech Republic, 1717-1730. http://dx.doi.org/10.1115/PVP2009-77044

Du, J. C.; Teng, H. C. 2007. 3D laser scanning and GPS technology for landslide earthwork volume estimation, Automation in Construction 16(5): 657-663.

http://dx.doi.org/10.1016/j.autcon.2006.11.002

Esmaeili, B.; Hallowell, M. R. 2012. Diffusion of safety innovations in the construction industry, Journal of Construction Engineering and Management 138(8): 955-963. http://dx.doi.org/10.1061/(asce)co.1943-7862.0000499

Fung, I. W. H.; Lee, Y. Y.; Tam, V. W. Y.; Fung, H. W. 2014. A feasibility study of introducing chin straps of safety helmets as a statutory requirement in Hong Kong construction industry, Safety Science 65: 70-78. http://dx.doi.org/10.1016/j.ssci.2013.12.014

Gao, W. X.; Hou, B. H.; Sun, X. M.; Deng, H. L.; Zhou, S. S.; Chen, N. N. 2012. Research on comprehensive information intelligent monitoring system for tunnel excavation, Yantu Lixue/Rock and Soil Mechanics 33(SUPPL. 2): 408-412.

Giretti, A.; Carbonari, A.; Naticchia, B.; Degrassi, M. 2009. Design and first development of an automated real-time safety management system for construction sites, Journal of Civil Engineering and Management 15(4): 325-336. http://dx.doi.org/10.3846/1392-3730.2009.15.325-336

Golparvar-Fard, M.; Pena-Mora, F.; Savarese, S. 2011. Integrated sequential as-built and as-planned representation with $\mathrm{D}(4) \mathrm{AR}$ tools in support of decision-making tasks in the AEC/FM industry, Journal of Construction Engineering and Management 137(12): 1099-1116. http://dx.doi.org/10.1061/(asce)co.1943-7862.0000371

Guo, J.; Ding, L.; Luo, H.; Zhou, C.; Ma, L. 2014. Wavelet prediction method for ground deformation induced by tunneling, Tunnelling and Underground Space Technology 41: 137-151. http://dx.doi.org/10.1016/j.tust.2013.12.009

Guo, J.; Zhang, H.; Liu, Y.; Liu, H.; Wang, P. 2011. Study on the data transmission technology of line condition monitoring system of smart transmission grid, Zhongguo Dianji Gongcheng Xuebao/Proceedings of the Chinese Society of Electrical Engineering 31(SUPPL. 1): 45-49. 
Hamidi, N.; Omidvari, M.; Meftahi, M. 2012. The effect of integrated management system on safety and productivity indices: case study; Iranian cement industries, Safety Science 50(5): 1180-1189.

http://dx.doi.org/10.1016/j.ssci.2012.01.004

Hammad, A.; Vahdatikhaki, F.; Zhang, C. 2013. A novel integrated approach to project-level Automated Machine Control/Guidance systems in construction projects, Journal of Information Technology in Construction 18: 162-181. http://www.itcon.org/2013/9

Han, C. S.; Lee, S. Y.; Lee, K. Y.; Park, B. S. 2006. A multidegree-of-freedom manipulator for curtain-wall installation, Journal of Field Robotics 23(5): 347-360.

http://dx.doi.org/10.1002/rob.20122

Han, S.; Saba, F.; Lee, S.; Mohamed, Y.; Pena-Mora, F. 2014. Toward an understanding of the impact of production pressure on safety performance in construction operations, Accident Analysis and Prevention 68: 106-116. http://dx.doi.org/10.1016/j.aap.2013.10.007

Hinze, J.; Hallowell, M.; Baud, K. 2013. Construction-safety best practices and relationships to safety performance, $\mathrm{Jo}$ urnal of Construction Engineering and Management 139(10): 8 . http://dx.doi.org/10.1061/(asce)co.1943-7862.0000751

Hu, Z.; Zhang, J.; Zhang, X. 2010a. Construction collision detection for site entities based on 4-D space-time model, Qinghua Daxue Xuebao/Journal of Tsinghua University 50(6): 820-825.

Hu, Z. Z.; Zhang, J. P.; Zhang, X. L. 2010b. 4D construction safety information model-based safety analysis approach for scaffold system during construction, Gongcheng Lixue/Engineering Mechanics 27(12): 192-200.

Huang, Y. 2012. Research on information management of tunnel safe construction, Applied Mechanics and Materials 209-211: 1500-1504.

http://dx.doi.org/10.4028/www.scientific.net/AMM.209211.1500

Hwang, S. 2012. Ultra-wide band technology experiments for real-time prevention of tower crane collisions, Automation in Construction 22: 545-553.

http://dx.doi.org/10.1016/j.autcon.2011.11.015

John, G.; Ganah, A. 2011. Integrating BIM and planning software for health and safety site induction, in Proceedings of RICS Construction and Property Conference (COBRA 2011), 2011, Salford, United Kingdom, 914-923.

Jung, K.; Chu, B.; Park, S.; Hong, D. 2013. An implementation of a teleoperation system for robotic beam assembly in construction, International Journal of Precision Engineering and Manufacturing 14(3): 351-358. http://dx.doi.org/10.1007/s12541-013-0049-3

Kamardeen, I. 2013. OHS electronic management systems for construction. Hoboken: Taylor and Francis. 150 p.

Karliński, J.; Ptak, M.; Działak, P. 2013. Simulation tests of roll-over protection structure, Archives of Civil and Mechanical Engineering 13(1): 57-63.

http://dx.doi.org/10.1016/j.acme.2012.12.001

Kasirossafar, M.; Shahbodaghlou, F. 2013a. Application of visualization technologies to design for safety concept, in Gateway to a Better Tomorrow - Proceedings of the $6^{\text {th }}$ Congress on Forensic Engineering, 2013, San Francisco, CA, United States, 370-377.

http://dx.doi.org/10.1061/9780784412640.040

Kasirossafar, M.; Shahbodaghlou, F. 2013b. Building information modeling for construction safety planning, in Developing the Frontier of Sustainable Design, Engineering, and Construction - Proceedings of the 2012 International
Conference on Sustainable Design and Construction (ICSDEC 2012), 2012, Fort Worth, TX, United States, 1017-1024.

http://dx.doi.org/10.1061/9780784412688.120

Kelm, A.; Laussat, L.; Meins-Becker, A.; Platz, D.; Khazaee, M. J.; Costin, A. M.; Helmus, M.; Teizer, J. 2013. Mobile passive Radio Frequency Identification (RFID) portal for automated and rapid control of Personal Protective Equipment (PPE) on construction sites, Automation in Construction 36: 38-52.

http://dx.doi.org/10.1016/j.autcon.2013.08.009

Kim, H. J.; Park, C. S. 2013. Smartphone based real-time location tracking system for automatic risk alert in building project, Applied Mechanics and Materials 256-259: 2794-2797.

http://dx.doi.org/10.4028/www.scientific.net/AMM.256259.2794

Kim, K. T.; Elernold, L. E. 2008. A comparison of two innovative technologies for safe pipe installation - "Pipeman" and the Stewart-Gough platform-based pipe manipulator, Automation in Construction 17(3): 322-332. http://dx.doi.org/10.1016/j.autcon.2007.04.004

Kim, S.; Shin, D. H.; Woo, S.; Lee, S. 2014. Identification of IT application areas and potential solutions for perception enhancement to improve construction safety, KSCE Journal of Civil Engineering 18(2): 365-379. http://dx.doi.org/10.1007/s12205-014-0173-3

Kim, Y. S.; Lee, J. H.; Yoo, H. S.; Lee, J. B.; Jung, U. S. 2009. A performance evaluation of a Stewart platform based Hume concrete pipe manipulator, Automation in Construction 18(5): 665-676. http://dx.doi.org/10.1016/j.autcon.2009.02.003

Kiviniemi, M.; Sulankivi, K.; Kähkönen, K.; Mäkelä, T.; Merivirta, M. L. 2011. BIM-based safety management and communication for building construction, VTT Tiedotteita-Valtion Teknillinen Tutkimuskeskus 2597, 1-123.

Kivrak, S.; Arslan, G.; Akgun, A.; Arslan, V. 2013. Augmented reality system applications in construction project activities, in $30^{\text {th }}$ International Symposium on Automation and Robotics in Construction and Mining, Held in Conjunction with the $23^{\text {rd }}$ World Mining Congress (ISARC 2013), 11-15 August 2013, Montreal, QC, Canada, 15601571 .

Lee, G.; Cho, J.; Ham, S.; Lee, T.; Yun, S. H.; Yang, H. J. 2012a. A BIM- and sensor-based tower crane navigation system for blind lifts, Automation in Construction 26: 110. http://dx.doi.org/10.1016/j.autcon.2012.05.002

Lee, G.; Kim, H. H.; Lee, C. J.; Ham, S. I.; Yun, S. H.; Cho, H.; Kim, B. K.; Kim, G. T.; Kim, K. 2009. A lasertechnology-based lifting-path tracking system for a robotic tower crane, Automation in Construction 18(7): 865874. http://dx.doi.org/10.1016/j.autcon.2009.03.011

Lee, H. S.; Lee, K. P.; Park, M.; Baek, Y.; Lee, S. 2012 b. RFID-based real-time locating system for construction safety management, Journal of Computing in Civil Engineering 26(3): 366-377. http://dx.doi.org/10.1061/(asce)cp.1943-5487.0000144

Lee, K.-P.; Lee, H.-S.; Park, M.; Kim, H.; Han, S. 2014. A realtime location-based construction labor safety management system, Journal of Civil Engineering and Management 20(5): 724-736. http://dx.doi.org/10.3846/13923730.2013.802728

Li, C.; Zhang, X.; Liu, X. 2012a. Mine safety information technology in the framework of Digital Mine, Safety Science 50(4): 846-850.

http://dx.doi.org/10.1016/j.ssci.2011.08.022 
Li, G.; Ding, L.; Wu, X.; Luo, H.; Li, X. 2007. Ground settlement prediction during construction of Wuhan Yangtze River Tunnel, Yanshilixue Yu Gongcheng Xuebao/Chinese Journal of Rock Mechanics and Engineering 26(SUPPL. 2): 3631-3638.

Li, J.; Hua, Z. 2012. An object library approach for managing construction safety component based on BIM, in 2012 Proceedings of the $29^{\text {th }}$ International Symposium of Automation and Robotics in Construction (ISARC 2012), 2012, Eindhoven, Netherlands. 6 p.

Li, N.; Li, S.; Becerik-Gerber, B.; Calis, G. 2012b. Deployment strategies and performance evaluation of a virtual-tagenabled indoor location sensing approach, Journal of Computing in Civil Engineering 26(5): 574-583. http://dx.doi.org/10.1061/(ASCE)CP.1943-5487.0000161

Li, X. P.; Gu, L. C.; Jia, J. 2012c. Anti-collision method of tower crane via ultrasonic multi-sensor fusion, in International Conference on Automatic Control and Artificial Intelligence (ACAI 2012), 24-26 March 2012, Xiamen, China. 522-525. http://dx.doi.org/10.1049/cp.2012.1031

Li, Y. F.; Wang, H. C.; Zhao, X. F.; Zhang, J. 2013. Research on BIM technology application in the construction of a subway station, Applied Mechanics and Materials 405408: 3396-3400.

http://dx.doi.org/10.4028/www.scientific.net/AMM.405408.3396

Liaudanskiene, R.; Simanaviciene, R.; Ustinovichius, L. 2012. A model for solving structural, technological and safety problems, Journal of Civil Engineering and Management 18(1): 30-42. http://dx.doi.org/10.3846/13923730.2011.643551

Luo, X.; O'Brien, W. J.; Leite, F. 2013. Evaluating the impact of location-aware sensor data imperfections on autonomous jobsite safety monitoring, in Computing in Civil Engineering - Proceedings of the 2013 ASCE International Workshop on Computing in Civil Engineering (ASCE 2013), 23-25 June 2013, Los Angeles, CA, United States, 573-580. http://dx.doi.org/10.1061/9780784413029.072

Lv, Y.; Zhu, Y. 2009. Research of the application of GIS and Sensor network in the building settlement observation, in Proceedings of the International Society for Optical Engineering (SPIE 2009), 16 October 2009, Wuhan, China. http://dx.doi.org/10.1117/12.838290

Ma, L.; Ding, L.; Luo, H. 2014. Non-linear description of ground settlement over twin tunnels in soil, Tunnelling and Underground Space Technology 42: 144-151. http://dx.doi.org/10.1016/j.tust.2014.02.006

Maalek, R.; Sadeghpour, F. 2011. A comparative overview of radio frequency-based technologies applicable to locating resources on construction sites, in Annual Conference of Canadian Society for Civil Engineering (CSCE 2011), 14-17 June 2011, Ottawa, ON, Canada, 2825-2835.

Maalek, R.; Sadeghpour, F. 2013. Accuracy assessment of Ultra-Wide Band technology in tracking static resources in indoor construction scenarios, Automation in Construction 30: 170-183. http://dx.doi.org/10.1016/j.autcon.2012.10.005

Marks, E.; Teizer, J. 2013. Evaluation of the position and orientation of (Semi-) passive RFID tags for the potential application in ground worker proximity detection and alert devices in safer construction equipment operation, in 2013 ASCE International Workshop on Computing in Civil Engineering (IWCCE 2013), 23-25 June 2013, Los Angeles, CA, United States, 645-652.

http://dx.doi.org/10.1061/9780784413029.081
Marks, E. D.; Cheng, T.; Teizer, J. 2013. Laser scanning for safe equipment design that increases operator visibility by measuring blind spots, Journal of Construction Engineering and Management 139(8): 1006-1014.

http://dx.doi.org/10.1061/(asce)co.1943-7862.0000690

Marzouk, M.; Ali, H. 2013. Modeling safety considerations and space limitations in piling operations using agent based simulation, Expert Systems with Applications 40(12): 4848-4857. http://dx.doi.org/10.1016/j.eswa.2013.02.021

Melzner, J.; Teizer, J.; Zhang, S.; Bargstadt, H. J. 2013. Objectoriented safety planning of building construction by using Building Information Modeling, Bauingenieur 88: 471479.

Meng, L.; Li, T.; Fang, X. 2010a. Development and application of tunnel geological prediction online consultation platform, in Proceedings - 2010 International Conference on Optoelectronics and Image Processing (ICOIP 2010), 1112 November 2010, Haiko, China, 421-424. http://dx.doi.org/10.1109/ICOIP.2010.16

Meng, Y.; Xu, W.; Liu, Z.; Liu, D.; Cai, D. 2010b. Analysis of 3D visualization of safety monitoring for complicated high rock slope engineering, Yanshilixue Yu Gongcheng Xuebao/Chinese Journal of Rock Mechanics and Engineering 29(12): 2500-2509.

Moon, H.; Dawood, N.; Kang, L. 2014a. Development of workspace conflict visualization system using 4D object of work schedule, Advanced Engineering Informatics 28(1): 50-65. http://dx.doi.org/10.1016/j.aei.2013.12.001

Moon, H.; Kim, H.; Kim, C.; Kang, L. 2014b. Development of a schedule-workspace interference management system simultaneously considering the overlap level of parallel schedules and workspaces, Automation in Construction 39: 93-105.

http://dx.doi.org/10.1016/j.autcon.2013.06.001

Nadar, M. A.; Awakian, C. A.; Khoury, H. K. 2013. An intelligent system for monitoring tower cranes on construction sites, in 30th International Symposium on Automation and Robotics in Construction and Mining, Held in Conjunction with the $23^{\text {rd }}$ World Mining Congress (ISARC 2013), Montreal, QC, Canada, 1239-1246.

Naticchia, B.; Vaccarini, M.; Carbonari, A. 2013. A monitoring system for real-time interference control on large construction sites, Automation in Construction 29: 148-160. http://dx.doi.org/10.1016/j.autcon.2012.09.016

Nuntasunti, S.; Bernold, L. E. 2006. Experimental assessment of wireless construction technologies, Journal of Construction Engineering and Management 132(9): 10091018. http://dx.doi.org/10.1061/(ASCE)0733-9364(2006) 132:9(1009)

Park, T.; Kim, M. K.; Kim, C.; Kim, H. 2009. Interactive 3D CAD for effective derrick crane operation in a cablestayed bridge construction, Journal of Construction Engineering and Management 135(11): 1261-1270. http://dx.doi.org/10.1061/(asce)co.1943-7862.0000101

Patel, A.; Chasey, A.; Ariaratnam, S. T. 2010. Integrating global positioning system with laser technology to capture asbuilt information during open-cut construction, Journal of Pipeline Systems Engineering and Practice 1(4): 147155. http://dx.doi.org/10.1061/(ASCE)PS.1949-1204.0000065

Peinado, S. P.; Rico, A. J. V.; Cañón, J. V.; De Las Heras, J. J.; Mieres, J. M. 2009. RFID-based quality and safety building site improvement during execution phase, in Annual Conference of the IEEE Industrial Electronics Society (IECON 2009), 3-5 November 2009, Porto, Portugal, 2659-2664.

http://dx.doi.org/10.1109/IECON.2009.5415253 
Qi, S.; Ding, L.; Luo, H. 2010. Study on integration and management system of schedule in large complex construction engineering projects based on lean construction, in 2010 International Forum on Information Technology and Applications (IFITA 2010), 16-18 July 2010, Kunming, China, 237-240. http://dx.doi.org/10.1109/ifita.2010.113

Qin, Y. P. 2013. Application of virtual reality technology in construction control and management, Applied Mechanics and Materials 427-429: 2851-2854.

http://dx.doi.org/10.4028/www.scientific.net/AMM.427429.2851

Razavi, S. N.; Montaser, A.; Moselhi, O. 2012. RFID deployment protocols for indoor construction, Construction Innovation 12(2): 239-258.

http://dx.doi.org/10.1108/14714171211215967

Ren, G. F.; Hu, Z. C.; Liu, Y. C.; Zhao, L. K.; Zhang, S. S. 2012. Design of safety monitoring collection and processing system on new tunnel excavation under exiting railway line, Wuhan Ligong Daxue Xuebao/Journal of Wuhan University of Technology 34(9): 80-83. http://dx.doi.org/10.3963/j.issn.1671-4431.2012.09.017

Rubio-Romero, J. C.; Rubio, M. C.; Garcia-Hernandez, C. 2013. Analysis of construction equipment safety in temporary work at height, Journal of Construction Engineering and Management 139(1): 9-14. http://dx.doi.org/10.1061/(asce)co.1943-7862.0000567

Saidi, K. S.; Teizer, J.; Franaszek, M.; Lytle, A. M. 2011. Static and dynamic performance evaluation of a commerciallyavailable ultra wideband tracking system, Automation in Construction 20(5): 519-530. http://dx.doi.org/10.1016/j.autcon.2010.11.018

Schikora, K.; Piegendorfer, M.; Filus, M. 2013. Plane and threedimensional analysis in tunneling using the example of current and planned construction, Beton- Und Stahlbetonbau 108(4): 252-263.

http://dx.doi.org/10.1002/best.201200084

Seo, J.; Lee, S.; Kim, J.; Kim, S. K. 2011. Task planner design for an automated excavation system, Automation in Construction 20(7): 954-966.

http://dx.doi.org/10.1016/j.autcon.2011.03.013

Sepasgozar, S. M. E.; Bernold, L. E. 2013. Factors influencing the decision of technology adoption in construction, in Developing the Frontier of Sustainable Design, Engineering, and Construction - Proceedings of the 2012 International Conference on Sustainable Design and Construction (ICSDEC 2012), 2012, Fort Worth, TX, United States, 654-661. http://dx.doi.org/10.1061/9780784412688.078

Shen, Z.; Zhu, Y. 2011. Complex engineering system learning through study of engineering failure cases using 3D animations, in ASEE Annual Conference and Exposition, 2011, Vancouver, BC, Canada. 16 p.

Shin, J. M.; Kim, S. Y.; Kim, G. H.; Jung, M. G.; Shin, D. W. 2014. Ubiquitous sensor network for construction site monitoring, Advanced Materials Research 919-921: 388391.

http://dx.doi.org/10.4028/www.scientific.net/AMR.919921.388

Siebert, S.; Teizer, J. 2014. Mobile 3D mapping for surveying earthwork projects using an Unmanned Aerial Vehicle (UAV) system, Automation in Construction 41: 1-14. http://dx.doi.org/10.1016/j.autcon.2014.01.004

Simanaviciene, R.; Liaudanskiene, R.; Ustinovichius, L. 2012. A new synthesis method of structural, technological and safety decisions (SyMAD-3), Journal of Civil Engineering and Management 18(2): 265-276.

http://dx.doi.org/10.3846/13923730.2012.666504
Simanaviciene, R.; Liaudanskiene, R.; Ustinovichius, L. 2014. Assessing reliability of design, construction, and safety related decisions, Automation in Construction 39: 47-58. http://dx.doi.org/10.1016/j.autcon.2013.11.008

Skibniewski, M. J. 1988. Robotics in civil engineering. Southampton, Boston, New York: Computational Mechanics, Van Nostrand Reinhold. 233 p.

Skibniewski, M. J. 2014. Research trends in information technology applications in construction safety engineering and management, in Frontiers of engineering management, vol. 3. Chinese Academy of Engineering, China. http://dx.doi.org/10.15302/J-FEM-2014034

Sparer, E. H.; Dennerlein, J. T. 2013. Determining safety inspection thresholds for employee incentives programs on construction sites, Safety Science 51(1): 77-84. http://dx.doi.org/10.1016/j.ssci.2012.06.009

Sulankivi, K.; Mäkelä, T.; Kiviniemi, M. 2009. BIM-based site layout and safety planning, VTT Symposium (Valtion Teknillinen Tutkimuskeskus) 259, 125-140.

Syachrani, S.; Jeong, H. S.; Rai, V.; Chae, M. J.; Iseley, T. 2010. A risk management approach to safety assessment of trenchless technologies for culvert rehabilitation, Tunnelling and Underground Space Technology 25(6): 681-688. http://dx.doi.org/10.1016/j.tust.2010.05.005

Talmaki, S. A.; Dong, S.; Kamat, V. R. 2010. Geospatial Databases and Augmented Reality visualization for improving safety in urban excavation operations, in Innovation for Reshaping Construction Practice - Proceedings of the 2010 Construction Research Congress, 2010, Banff, AB, Canada, 91-101. http://dx.doi.org/10.1061/41109(373)10

Tam, V. W. Y.; Fung, I. W. H. 2011. Tower crane safety in the construction industry: a Hong Kong study, Safety Science 49(2): 208-215.

http://dx.doi.org/10.1016/j.ssci.2010.08.001

Tang, X.; Yamada, H. 2011. Tele-operation construction robot control system with virtual reality technology, in 2011 International Conference on Advanced in Control Engineering and Information Science, 2011, Dali, China, 1071-1076. http://dx.doi.org/10.1016/j.proeng.2011.08.198

Teizer, J. 2007. Automated monitoring of construction processes for management decision making, in Construction and Building Research Conference of the Royal Institution of Chartered Surveyors (COBRA 2007), 2007, Atlanta, GA, United States.

Teizer, J.; Allread, B. S.; Mantripragada, U. 2010. Automating the blind spot measurement of construction equipment, Automation in Construction 19(4): 491-501.

http://dx.doi.org/10.1016/j.autcon.2009.12.012

Teizer, J.; Castro-Lacouture, D. 2007. Combined ultrawideband positioning and range imaging sensing for productivity and safety monitoring in building construction, in Congress on Computing in Civil Engineering (ASCE 2007), 2007, Pittsburgh, PA, United States, 681-688. http://dx.doi.org/10.1061/40937(261)81

Teizer, J.; Lao, D.; Sofer, M. 2007. Rapid automated monitoring of construction site activities using ultra-wideband, in Proceedings of the $24^{\text {th }}$ International Symposium on Automation and Robotics in Construction (ISARC 2007), 19-21 September 2007, Kochi, India, 23-28.

Teizer, J.; Venugopal, M.; Walia, A. 2008. Ultrawideband for automated real-time three-dimensional location sensing for workforce, equipment, and material positioning and tracking, Transportation Research Record 2081: 56-64. http://dx.doi.org/10.3141/2081-06 
Wang, H. 2013. Environmental monitoring system based on ZigBee wireless sensor and low-power technology, Advanced Materials Research 662: 701-704. http://dx.doi.org/10.4028/www.scientific.net/AMR.662.701

Wang, Q.; Liu, W.; Gao, C.; Wang, F. 2011. Hardware design of monitoring and warning system for coal mine highvoltage power supply network, Advanced Materials Research 271-273: 1015-1019. http://dx.doi.org/10.4028/www.scientific.net/AMR.271273.1015

Wang, Q. K.; Wang, S. Q. 2009. Establishment of construction safety monitoring management information system for metro engineering, Wuhan Ligong Daxue Xuebao/Journal of Wuhan University of Technology 31(23): 72-76. http://dx.doi.org/10.3963/j.issn.1671-4431.2009.23.017

Wu, H.; Tao, J.; Li, X.; Chi, X.; Li, H.; Hua, X.; Yang, R.; Wang, S.; Chen, N. 2013a. A location based service approach for collision warning systems in concrete dam construction, Safety Science 51(1): 338-346. http://dx.doi.org/10.1016/j.ssci.2012.08.006

Wu, S. L.; Deng, H. L.; Chen, K. J.; Zhu, M. Y.; Huang, D. H.; Fu, S. Y. 2013b. Visual monitoring technology of the tunnel 3D laser scanning and engineering applications, Advanced Materials Research 779: 463-468. http://dx.doi.org/10.4028/www.scientific.net/AMR.779780.463

Wu, W. W.; Yang, H. J.; Chew, D. A. S.; Yang, S. H.; Gibb, A. G. F.; Li, Q. M. 2010. Towards an autonomous real-time tracking system of near-miss accidents on construction sites, Automation in Construction 19(2): 134-141. http://dx.doi.org/10.1016/j.autcon.2009.11.017

Xie, H.; Shi, W.; Issa, R. R. A. 2011. Using rfid and real-time virtual reality simulation for optimization in steel construction, Electronic Journal of Information Technology in Construction 16: 291-308. http://www.itcon.org/2011/19

Xue, Z.; Li, Y.; Chen, Z. 2011. Research on the dynamic intelligent management system of Highway Safety and Quality Control, Advanced Materials Research 271-273: 344350 .

http://dx.doi.org/10.4028/www.scientific.net/AMR.271273.344

Yamamoto, H.; Moteki, M.; Shao, H.; Ootuki, K.; Yanagisawa, Y.; Sakaida, Y.; Nozue, A.; Yamaguchi, T.; Yuta, S. 2010. Development of the autonomous hydraulic excavator prototype using 3-D information for motion planning and control, in 2010 IEEE/SICE International Symposium on System Integration: SI International 2010 - The $3^{\text {rd }}$ Symposium on System Integration (SII 2010), 21-22 December 2010, Sendai, Japan, 49-54. http://dx.doi.org/10.1109/SII.2010.5708300

Yang, H.; Chew, D. A. S.; Wu, W.; Zhou, Z.; Li, Q. 2012. Design and implementation of an identification system in construction site safety for proactive accident prevention, Accident Analysis and Prevention 48: 193-203. http://dx.doi.org/10.1016/j.aap.2011.06.017

Yang, J. G.; Ma, W. 2011. Application for fiber bragg grating sensor in internal force testing of lining structure, Advanced Materials Research 219-220: 746-749. http://dx.doi.org/10.4028/www.scientific.net/AMR.219220.746

Yang, Q.; Zheng, J.; Ding, L.; Zhang, R. 2010. Threedimensional numerical simulation of deep excavation adjacent to viaduct foundation, Huazhong Keji Daxue Xuebao (Ziran Kexue Ban)/Journal of Huazhong University of Science and Technology (Natural Science Edition) 38(6): 120-123, 128.
Ye, Y.; Mu, Q.; Zhang, C. 2009. Tunnel construction multivariate information forewarning and safety management system research, Yanshilixue Yu Gongcheng Xuebao/ Chinese Journal of Rock Mechanics and Engineering 28(5): 900-907.

Ye, Y.; Sun, W.; Yang, X.; Zhang, Z.; Wang, X. 2013. Informational early warning platform for tunnel construction, Modern Tunnelling Technology 50(4): 24-29.

Yoo, W. S.; Lee, H. J.; Kim, D. I.; Kang, K. I.; Cho, H. 2012. Genetic algorithm-based steel erection planning model for a construction automation system, Automation in Construction 24: 30-39. http://dx.doi.org/10.1016/j.autcon.2012.02.007

Yoon, S. W.; Chin, S.; Kim, Y. S.; Kwon, S. W. 2006. An application model of RFID technology on progress measurement and management of construction works, in 2006 Proceedings of the $23^{\text {rd }}$ International Symposium on Robotics and Automation in Construction (ISARC 2006), 3-5 November 2006, Tokyo, Japan, 779-783.

Zhang, J. P.; Hu, Z. Z. 2011. BIM- and 4D-based integrated solution of analysis and management for conflicts and structural safety problems during construction: 1. Principles and methodologies, Automation in Construction 20(2): 155-166. http://dx.doi.org/10.1016/j.autcon2010.09.013

Zhang, L.; Wu, X.; Ding, L.; Chen, Y.; Skibniewski, M. J. 2013a. Risk identification expert system for metro construction based on BIM, in $30^{\text {th }}$ International Symposium on Automation and Robotics in Construction and Mining, Held in Conjunction with the $23^{\text {rd }}$ World Mining Congress (ISARC 2013), 11-15 August 2013, Montreal, QC, Canada, 1437-1446.

Zhang, L.; Wu, X.; Ding, L.; Skibniewski, M. J.; Yan, Y. 2013b. Decision support analysis for safety control in complex project environments based on Bayesian Networks, Expert Systems with Applications 40(11): 4273-4282. http://dx.doi.org/10.1016/j.eswa.2012.11.022

Zhang, N. Q.; Yu, M.; Zhang, X.; Fu, J.; Wu, H. S. 2013c. Enhancing tower crane safety using condition monitoring system, Applied Mechanics and Materials 418: 80-83. http://dx.doi.org/10.4028/www.scientific.net/AMM.418.80

Zhang, Q. Y.; Chen, X. P.; Liu, D. W.; Hu, J. Z.; Li, J.; Cai, D. W. 2009. Development of monitoring information management and monitoring data analysis network system for geotechnical engineering and its application, Yantu Lixue/Rock and Soil Mechanics 30(2): 362-366, 373.

Zhang, S. J.; Teizer, J.; Lee, J. K.; Eastman, C. M.; Venugopal, M. 2013d. Building Information Modeling (BIM) and safety: automatic safety checking of construction models and schedules, Automation in Construction 29: 183-195. http://dx.doi.org/10.1016/j.autcon.2012.05.006

Zhao, D.; Ye, Y. 2012. Using virtual environments simulation to improve construction safety: an application of 3D online-game based training, Lecture Notes in Electrical Engineering 172 LNEE: 269-277.

http://dx.doi.org/10.1007/978-3-642-31006-5_33

Zhao, J.; Ju, H.; Li, J.; Liu, Y. 2012. The monitoring technology research about the tunnel blasting vibration under the complex construction, Advanced Materials Research 594597: 1078-1081.

http://dx.doi.org/10.4028/www.scientific.net/AMR.594597.1078

Zhou, Y.; Ding, L.; Chen, L. 2013a. Application of 4D visualization technology for safety management in metro construction, Automation in Construction 34: 25-36. http://dx.doi.org/10.1016/j.autcon.2012.10.011 
Zhou, Y.; Ding, L.; Luo, H.; Chen, L. 2010. Research and application on 6D integrated system in metro construction based on BIM, in 2010 International Conference on Advanced Mechanical Engineering (AME 2010), 2010, Luoyang, China, 241-245.

http://dx.doi.org/10.4028/www.scientific.net/AMM.2628.241

Zhou, Z.; Irizarry, J.; Li, Q. 2013b. Applying advanced technology to improve safety management in the construction industry: a literature review, Construction Management and Economics 31(6): 606-622.

http://dx.doi.org/10.1080/01446193.2013.798423
Zhou, Z. P.; Li, Q. M.; Wu, W. W. 2012. Developing a versatile subway construction incident database for safety management, Journal of Construction Engineering and Management 138(10): 1169-1180. http://dx.doi.org/10.1061/(asce)co.1943-7862.0000518

Zhu, X.; Xue, X.; Chen, M.; Zhou, H. 2013. Mobile IT used in construction: a case for scaffolding safety management, in Construction and Operation in the Context of Sustainability - Proceedings of the 2013 International Conference on Construction and Real Estate Management (ICCREM 2013), 10-11 October 2013, Karlsruhe, Germany, 482491. http://dx.doi.org/10.1061/9780784413135.046

Miroslaw J. SKIBNIEWSKI. Professor, leads the e-Construction Research Group in the Department of Civil and Environmental Engineering at the University of Maryland in College Park, USA. A former Professor and Assoc. Provost at Purdue University in West Lafayette, Indiana, USA, he holds a MEng degree in Civil Engineering from Warsaw University of Technology in Poland, and MS and PhD degrees in Civil Engineering Planning and Management from Carnegie Mellon University in Pittsburgh, Pennsylvania, USA. He is an author or co-author of over 200 research articles on a wide array of topics related to information technologies and automation for the construction industry. Prof. Skibniewski's research has been supported by the U.S. National Science Foundation, SAP-America, Fulbright and Humboldt Foundations, Bechtel Corporation, Obayashi Corporation and the Clark Construction Group, among others. He has been a recipient of the U.S. National Science Foundation's Presidential Young Investigator Award, American Society of Civil Engineers' Walter L. Huber Research Prize and the International Association for Automation and Robotics in Construction TuckerHasegawa Award for lifetime research achievements in construction automation. Prof. Skibniewski holds an honorary doctorate from Vilnius Gediminas Technical University. 